\title{
Fowkes方法による溶鉄中 $\mathrm{Al}_{2} \mathrm{O}_{3} / \mathrm{Al}_{2} \mathrm{O}_{3}$, $\mathrm{Al}_{2} \mathrm{O}_{3} /$ 気泡のHamaker定数の推算
}

\author{
林 煒*・眞目 薰*2
}

Estimation of Hamaker Constants of $\mathrm{Al}_{2} \mathrm{O}_{3} / \mathrm{Al}_{2} \mathrm{O}_{3}, \mathrm{Al}_{2} \mathrm{O}_{3} /$ Bubble in Molten Iron Using Fowkes's Method Wei Lin and Kaoru Shimme

Synopsis : The Hamaker constants of molten iron and $\mathrm{Al}_{2} \mathrm{O}_{3} / \mathrm{Al}_{2} \mathrm{O}_{3}$ and $\mathrm{Al}_{2} \mathrm{O}_{3} /$ bubble in molten iron at $1600^{\circ} \mathrm{C}\left(\mathrm{A}_{\mathrm{Fe}}, \mathrm{A}_{\mathrm{AFA}}, \mathrm{A}_{\mathrm{AFB}}\right)$ were estimated using Fowkes's method from the wettabilities and the Hamaker constant of $\mathrm{Al}_{2} \mathrm{O}_{3}$ at room temperature and the values obtained were as follows respectively:

$$
\begin{aligned}
& \mathrm{A}_{\mathrm{Fe}}=10.5 \times 10^{-19} \mathrm{~J} \\
& \mathrm{~A}_{\mathrm{AFA}}=3.98 \times 10^{-19} \mathrm{~J} \\
& \mathrm{~A}_{\mathrm{AFB}}=6.47 \times 10^{-19} \mathrm{~J}
\end{aligned}
$$

Then, coagulation coefficient of $\mathrm{Al}_{2} \mathrm{O}_{3}$ inclusions in turbulent molten steel and the separation rate of inclusions caused by the interaction with bubbles were estimated through using the Hamaker constants obtained to the theories reported by other researchers.

Key words : Hamaker constant ; van der Waals force ; alumina inclusion; bubble ; molten iron ; wettability ; coagulation coefficient ; separation rate.

\section{1. 緒言}

近年，溶鋼中介在物間(あるいは介在物と気泡間)の凝 集・分離の現象を定量的に把握す心゙くこれに関連する数 值シミュレーションの研究1)が，さかんに進められている。 しかしながら，解析に必要な溶鋼流れ場での介在物の凝集 係数は, まだ不明であるのが現状であり，その解明が重要 となっている。

一方，流体中の粒子間の凝集係数は，2つの粒子が接近 した際の粒子間力にかかわることが判明している2)。また， 溶鉄中酸化物の粒子間力としては, van der Waals力のみ を考えてもよいとする報告 ${ }^{3-5)}$ が従来からいくつかなされて おり, van der Waals力がわかれば，凝集係数を推定する ことが可能と考えられる。このvan der Waals力を求める には，溶鉄中酸化物のHamaker定数が必要である。さらに このHamaker定数を得るため, 溶鉄および酸化物のHamaker定数が必要である。しかしこれらの值の実測が現在で は難しい。

谷口ら ${ }^{5)}$ は, 従来から報告されている常温での固体鉄およ び酸化物のHamaker定数を用いて，鉄を媒質とする種々の 酸化物間および酸化物々気泡間のHamaker定数を推定した
が，この推定值が高温の溶鉄の場合に適用し得るかぼうか は不明であると述べている。

一方, Hamaker定数を得る方法の 1 つして, 表面張力 から求める方法が，Fowkesより提案されている6,7)。

本研究では, Fowkesの方法を用いて, 常温での $\mathrm{Al}_{2} \mathrm{O}_{3}$ の Hamaker定数および $1600^{\circ} \mathrm{C} て ゙ の$ 溶鉄と $\mathrm{Al}_{2} \mathrm{O}_{3}$ の付着仕事よ り，溶鉄の Hamaker定数および溶鉄中の $\mathrm{Al}_{2} \mathrm{O}_{3}$ 同士間 (以 下, $\left.\mathrm{Al}_{2} \mathrm{O}_{3} / \mathrm{Al}_{2} \mathrm{O}_{3}\right) \& \mathrm{Al}_{2} \mathrm{O}_{3}$ と気泡間 (以下, $\mathrm{Al}_{2} \mathrm{O}_{3} /$ 気泡) の それを推算した。また, 得られた值を溶鋼の場合に適用し, 溶鋼中 $\mathrm{Al}_{2} \mathrm{O}_{3}$ 介在物の凝集係数および微細な気泡の捕捉によ る介在物の除去速度について検討した。

\section{Fowkesの方法")の概要}

表面張力(あるいは表面エネルギー) бが分子間力によって 次のように加成的に展開できると仮定する。

$$
\sigma=\sigma^{\mathrm{d}}+\sigma^{\mathrm{m}}+\sigma^{\mathrm{i}}+\sigma^{\mathrm{h}}+\cdots
$$

$\sigma^{\mathrm{d}}$ は表面張力のvan der Waals力成分， $\sigma^{\mathrm{m}}$ は金属結合力 成分， $\sigma^{\mathrm{i}}$ はイオン結合力成分， $\sigma^{\mathrm{h}}$ は水素結合力成分なぼを 示す。その中でvan der Waals力成分はつねに存在してい

平成 9 年 2 月 $27 \mathrm{H}$ 受付 平成 9 年 7 月 3 日受理 (Received on Feb. 27, 1997; Accepted on July 3, 1997)

* 住友金属工業(株) 総合技術研究所（現：品川向煉瓦(株)技術研究所） (Corporate Research \& Development Laboratories, Sumitomo Metal Industries, Ltd., now Research Center, Shinagawa Refractories, Co., Ltd., 707 Inbe Bizen 705)

* 2 住友金属I.業(株) 総合技術研究所 (Corporate Research \& Development Laboratories, Sumitomo Metal Industries, Ltd.) 


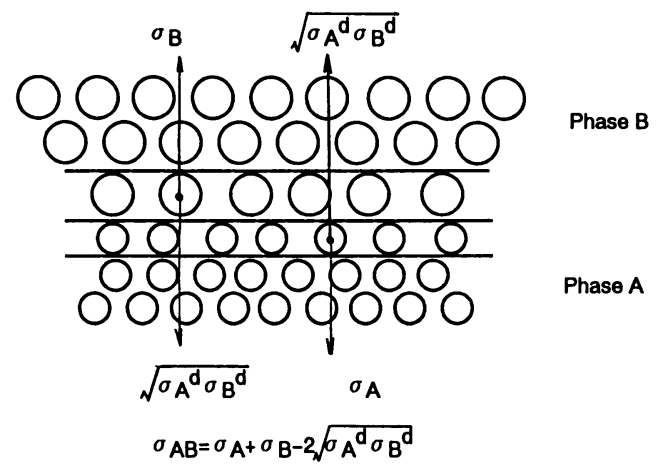

Fig. 1. Model for van der Waals forces operating across interface between phase $\mathrm{A}$ and $\mathrm{B}^{7}$.

る成分である。例えば，水銀，水の表面張力はそれぞれ次 のように展開される。

$$
\begin{aligned}
& \sigma_{\mathrm{Hg}}=\sigma^{\mathrm{d}}{ }_{\mathrm{Hg}}+\sigma^{\mathrm{m}}{ }_{\mathrm{Hg}} \\
& \sigma_{\mathrm{H} 2 \mathrm{O}}=\sigma^{\mathrm{d}}{ }_{\mathrm{H} 2 \mathrm{O}}+\sigma_{\mathrm{H} 2 \mathrm{O}}^{\mathrm{h}}
\end{aligned}
$$

б㘯がわかれば，Hamaker定数は（2）式により求められる。

$\mathrm{A}=6 \pi \mathrm{d}^{2} \sigma^{\mathrm{d}}$

ただし，dは原子あるいは分子間の距離である。 兇については，次のように求められる。

Fig. 1 に示すように，相Aと相Bの界面において，相Aの 表面層の分子は, 表面張力 $\sigma_{\mathrm{A}}$ を持っているが, 界面層では, 一方において相Aの分子から引力を受け，他方においては相 Bの分子からも引力を受ける。したがって，相 $\mathrm{A} の$ 界面層の 自由エネルギーは, 相 $\mathrm{A}$, 相Bの分子間力のある種の平均だ け表面層の自由エネルギーより減少している。るっとも理 論的に妥当と考えられる平均は相乗平均である。

もし界面には $\mathrm{A}$ と B に共通の分子間力であるvan der Waals力しか作用しなければ,相Bが存在するためにおこる 相Aの界面層の自由エネルギー減少高は, $\sqrt{\sigma_{\mathrm{A}}{ }^{\mathrm{d}} \sigma_{\mathrm{B}}{ }^{\mathrm{d}}}$ となる。 それゆえ，この層の内部に対する余分の自由エネルギーは $\sigma_{\mathrm{A}}-\sqrt{\sigma_{\mathrm{A}}{ }^{\mathrm{d}} \sigma_{\mathrm{B}}{ }^{\mathrm{d}}}$ で, 相Bの界面層では同じようにして $\sigma_{\mathrm{B}}-$ $\sqrt{\sigma_{A}{ }^{\mathrm{d}} \sigma_{\mathrm{B}}{ }^{\mathrm{d}}}$ となる。したがって, 相A と相Bの界面張力として は次の式が得られる。

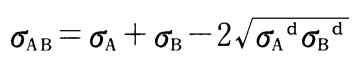

もし相Bを飽和炭化水素溶液とすれば,このような溶液中 の分子間力はvan der Waals力のみで， $\sigma_{\mathrm{B}}{ }^{\mathrm{d}}$ は表面張力 $\sigma_{\mathrm{B}}$ と 相等しくなり， $\sigma_{\mathrm{A}} ， \sigma_{\mathrm{B}} と \sigma_{\mathrm{AB}}$ がわかれば，(3)式にて相Aの $\sigma_{\mathrm{A}} \mathrm{d}^{\mathrm{d}}$ 求められる。

Fowkes ${ }^{7}$ は, 水銀あるいは水々種々の炭化水素溶液の系 を考えて，水銀または水の $\sigma^{\mathrm{d}}$ の值を算出した結果，異なる 炭化水素から求めた水銀あるいは水の $\sigma^{\mathrm{d} の}$ 值はかなりよく 一致しており，このような扱いが少なくとも近似的には妥 当なことがわかる。
Table 1. Hamaker constant of $\mathrm{Al}_{2} \mathrm{O}_{3}$ at room temperature reported by other investigators.

\begin{tabular}{|l|c|c|}
\hline Investigator & Ref. & $\mathrm{A}, \times 10^{-19} \mathrm{~J}$ \\
\hline H.Buttner et al. & 9 & 1.48 \\
G.Bohme et al. & 8 & 1.55 \\
D.B.Houng et al. & 10 & 1.56 \\
L.Bergstrom et al. & 11 & 1.60 \\
\hline
\end{tabular}

\section{Hamaker定数の計算}

\section{$3 \cdot 1$ 用いる関係式}

Fowkesの方法7の適用できる条件としては，2つの相の 界面においてvan der Waals力のみが作用し，また化学的 反応が起こらないことであると考えられる。後述するよう に，溶鉄中の酸素濃度がある範囲であれば，溶鉄 $\mathrm{Al}_{2} \mathrm{O}_{3}$ の 場合には，この 2 つ条件が満足されると考えられる。

(2) と (3) 式より，1 つの相のHamaker定数, 2 つの相 の表面張力およびその間の界面張力がわかっていれば， も う1つの相のHamaker定数は求められることがわかる。

以下, 常温から $1600^{\circ} \mathrm{C}$ まで $\mathrm{Al}_{2} \mathrm{O}_{3}$ のHamaker定数の变化 が小さいと仮定し, $1600^{\circ} \mathrm{C} て ゙ の ~ \mathrm{Al}_{2} \mathrm{O}_{3}$ のHamaker定数とし て, 常温でのその値を用いる。この仮定の妥当性について の検討は, 後述する $4 \cdot 2$ 節で行う。

常温での $\mathrm{Al}_{2} \mathrm{O}_{3}$ のHamaker定数は, 従来からいくつか報

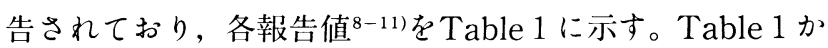
ら，これらの報告值はよく一致していることがわかる。本 研究では, $\mathrm{Al}_{2} \mathrm{O}_{3}$ のHamaker定数としてその中間值の $1.55 \times$ $10^{-19} \mathrm{~J}$ 用いる。

このようにすると, (2) と（3)式から（4)式が得られる。

$$
\begin{aligned}
\mathrm{A}_{\mathrm{Fe}} & =6 \pi \mathrm{d}_{\mathrm{Fe}}{ }^{2} \sigma_{\mathrm{Fe}}{ }^{\mathrm{d}} \\
& =9 \pi^{2} \mathrm{~d}_{\mathrm{Fe}}{ }^{2} \mathrm{~d}_{\mathrm{Al}_{2} \mathrm{O}_{3}}{ }^{2}\left[\sigma_{\mathrm{Fe}}+\sigma_{\mathrm{Al}_{2} \mathrm{O}_{3}}-\sigma_{\mathrm{Fe}} /{ }_{\mathrm{Al} 2 \mathrm{O}_{3}}\right]^{2}
\end{aligned}
$$$$
/ \mathrm{A}_{\mathrm{Al}_{2} \mathrm{O}_{3}}
$$

Youngの式を上式に適用すると，

$$
\begin{aligned}
\mathrm{A}_{\mathrm{Fe}} & =9 \pi^{2} \mathrm{~d}_{\mathrm{Fe}^{2}} \mathrm{~d}_{\mathrm{Al}_{20}{ }_{3}}\left[\sigma_{\mathrm{Fe}}(1+\cos \theta)\right]^{2} / \mathrm{A}_{\mathrm{Al} 2 \mathrm{O}_{3}} \\
& =9 \pi^{2} \mathrm{~d}_{\mathrm{Fe}^{2}}{ }^{2} \mathrm{~d}_{\mathrm{Al}_{2} \mathrm{O}_{3}}{ }^{2}\left(\mathrm{~W}_{\mathrm{ad}}\right)^{2} / \mathrm{A}_{\mathrm{Al} 2 \mathrm{O}_{3}} \ldots \ldots \ldots \ldots \ldots \ldots \ldots
\end{aligned}
$$

(4)，（5）式において， $\mathrm{A}_{\mathrm{Fe}} ， \mathrm{~A}_{\mathrm{Al}_{2} \mathrm{O} 3}$ はそれぞれ溶鉄およ び $\mathrm{Al}_{2} \mathrm{O}_{3}$ のHamaker定数， $\sigma_{\mathrm{Fe}} ， \sigma_{\mathrm{Al}_{2} \mathrm{O}_{3}}$ はそれぞれ溶鉄および $\mathrm{Al}_{2} \mathrm{O}_{3}$ の表面張力, $\sigma_{\mathrm{Fe}} / \mathrm{Al}_{20}$ はそ等間の界面張力, $\sigma_{\mathrm{Fe}}{ }^{\mathrm{d}}$ は溶 鉄の表面張力中のvan der Waals力成分， $\theta$ と $\mathrm{W}_{\mathrm{ad}}$ はそれぞ れ溶鉄と $\mathrm{Al}_{2} \mathrm{O}_{3}$ の接触角および付着仕事である。また， $\mathrm{d}_{\mathrm{Fe}}$ $と \mathrm{~d}_{\mathrm{Al}_{2} \mathrm{O}_{3}}$ はそれぞれ溶鉄の原子間距離および $\mathrm{Al}_{2} \mathrm{O}_{3}$ の分子間距 離である。

\section{$3 \cdot 2$ 溶鉄と $\mathrm{Al}_{2} \mathrm{O}_{3}$ 間の相互作用力および付着仕事}

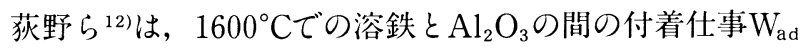
t測定し， $0.84 \mathrm{~J} / \mathrm{m}^{2}$ の值が得られた。さらに，彼らは， $\mathrm{W}_{\mathrm{ad}}$ 
を 1 モルの物質が原子( 1 分子)の厚さに広がるときの表面 エネルギーの变化 $\mathrm{W}_{\mathrm{a}, \mathrm{mol}}$ に換算し， $\mathrm{W}_{\mathrm{a}, \mathrm{mol}}$ は $15.8 \mathrm{kcal} / \mathrm{mol}$ あることを示した。また，この付着仕事は，固相一液相界 面での結合の強さをあらわすものであり, 通常, 分散力 (van der Waals力)による結合エネルギーが $5 \sim 10 \mathrm{kcal} / \mathrm{mol}$, 化

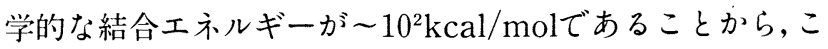
の場合の溶鉄と $\mathrm{Al}_{2} \mathrm{O}_{3}$ の界面においては分散力による結合が 支配的であると述べている。

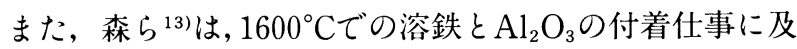
ぼす溶鉄中の酸素濃度の影響について調へ，溶鉄中の酸素 濃度が50～60ppmを境にして，低酸素領域では，酸素濃度 の減少にともない付着仕事が急激に増加するが, 高酸素領 域では, 酸素濃度の増加にともない付着仕事がゆるやかに 上昇する実験結果を示した。さらに彼らは，これは，溶鉄 中酸素濃度が50 60ppm以下では $\mathrm{Al}_{2} \mathrm{O}_{3}$ の解離反応が起こ り，50〜60ppm以上では溶鉄から $\mathrm{FeO}^{\circ} \mathrm{Al}_{2} \mathrm{O}_{3}$ に浸透する反 応が起こり，ハーシナイト $\left(\mathrm{FeO} \cdot \mathrm{Al}_{2} \mathrm{O}_{3}\right)$ が生じるためと説 明した。

これによると, $\mathrm{Al}_{2} \mathrm{O}_{3}$ が安定に存在し得る溶鉄中の酸素濃 度は，50〜60ppmであると思われる。このときの溶鉄と

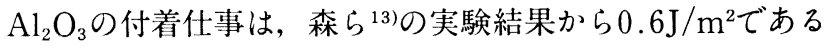
ことがわかる。荻野ら ${ }^{12)}$ と同様の方法で $\mathrm{W}_{\mathrm{ad}}$ をW $\mathrm{W}_{\mathrm{ad}, \mathrm{mol}}$ に換算 すると, 約 $10 \mathrm{kcal} / \mathrm{mol}$ なる。これは,この際の溶鉄と $\mathrm{Al}_{2} \mathrm{O}_{3}$ 間にはほぼvan der Waals力のみが存在することを示 していると思われる。従って，この場合には（５)式が適用 できると考えられる。それゆえ，以下の計算においてW して0.6J/m²用いる。

\section{$3 \cdot 3$ 計算結果}

$1600^{\circ} \mathrm{Cにおける} \mathrm{d}_{\mathrm{Fe}}$ について，早稲田ら ${ }^{14) に よ る と ， 2.58 \times ~}$ $10^{-10} \mathrm{~m} て ゙ あ り, \mathrm{~d}_{\mathrm{A} 12_{2} \mathrm{O}_{3}}$ については, Fowkes ${ }^{7)}$ によると, 2.76× $10^{-10} \mathrm{~m}$ の值である。

$\mathrm{A}_{\mathrm{Al}_{2} \mathrm{O}_{3}}=1.55 \times 10^{-19} \mathrm{~J}, \mathrm{~W}_{\mathrm{ad}}=0.6 \mathrm{~J} / \mathrm{m}^{2}, \mathrm{~d}_{\mathrm{Fe}}=2.58 \times 10^{-10} \mathrm{~m}$

$\mathrm{d}_{\mathrm{Al}_{2} \mathrm{O}_{3}}=2.76 \times 10^{-10} \mathrm{~m} と し て, \quad(5)$ 式より求めた $\mathrm{A}_{\mathrm{Fe}}$ は, $10.5 \times 10^{-19} \mathrm{~J}$ なる。

また, 従来の $(6),(7)$ 式15)を用いて, 溶鉄中の $\mathrm{Al}_{2} \mathrm{O}_{3} /$ $\mathrm{Al}_{2} \mathrm{O}_{3}$ およ゙ $\mathrm{Al}_{2} \mathrm{O}_{3} /$ 気泡のHamaker定数 $\mathrm{A}_{\mathrm{AFA}}, \mathrm{A}_{\mathrm{AFB}}$ を算出

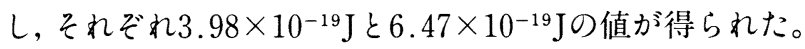

$$
\begin{aligned}
& \mathrm{A}_{\mathrm{AFA}}=\left(\sqrt{\mathrm{A}_{\mathrm{Fe}}}-\sqrt{\mathrm{A}_{\mathrm{Al}_{2} \mathrm{O}_{3}}}\right)^{2} \ldots \ldots \ldots \\
& \mathrm{A}_{\mathrm{AFB}}=-\sqrt{\mathrm{A}_{\mathrm{Fe}}}\left(\sqrt{\mathrm{A}_{\mathrm{Al}_{2} \mathrm{O}_{3}}}-\sqrt{\mathrm{A}_{\mathrm{Fe}}}\right)
\end{aligned}
$$

\section{4. 考察}

\section{$4 \cdot 1$ 本研究で得られた $A_{\mathrm{Fe}}, \mathrm{A}_{\mathrm{AFA}}, \mathrm{A}_{\mathrm{AFB}}$ の值の妥当性および 従来の值との比較}

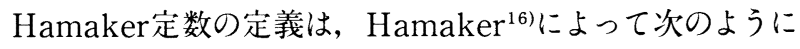
与えられている。

$$
A=(3 / 4) \pi^{2} q^{2} \alpha^{2} I
$$

ただし，qは単位体積中の原子数， $\alpha ， \mathrm{I}$ はそれぞれ原子 または分子の分極率およびイオン化ポテンシャルである。

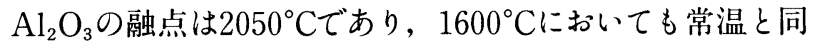
様に固相であるため, 常温から $1600^{\circ} \mathrm{C} ま て ゙ \mathrm{Al}_{2} \mathrm{O}_{3}$ の $\mathrm{q}$ の值の 変化は極めて小さいと考えられる。

$\alpha$, Iについては, その温度依存性が明確にされていない。 しかし,この 2 つのパラメーターはいずれも原子または分 子の運動にかかわり, 固相を保つ温度範囲では, 原子また は分子の運動があまり変わらないと考えれば，常温から $1600^{\circ} \mathrm{C}$ まで $\mathrm{Al}_{2} \mathrm{O}_{3}$ の $\alpha, \mathrm{I}$ の值の変化も小さいと推定される。

以上の検討によって, 本研究で $\mathrm{A}_{\mathrm{Al}_{2} \mathrm{O}_{3}}$ して常温での值を 用いることに起因して生じた誤差が小さいと推定される。

一方，(4)式から， $\mathrm{A}_{\mathrm{Fe}}$ は $\mathrm{d}_{\mathrm{Fe}} お よ ひ ゙ \sigma_{\mathrm{Fe}}{ }^{\mathrm{d}}$ 少り決まること がわかる。 $\mathrm{d}_{\mathrm{Fe}}$ としては早稲田ら ${ }^{14)}$ の測定值を用いたため, $\sigma_{\mathrm{Fe}}{ }^{\mathrm{d}}$ の計算值が妥当であれば, 得られた $\mathrm{A}_{\mathrm{Fe}}$ の值も妥当であ ると思われる。以下, 種々の溶融金属の $\sigma^{\mathrm{d}}$ 求め, 各溶融 金属の $\sigma^{\mathrm{d}} / \sigma$ (表面張力に占めるvan der Waals力成分の比 率)の值を比較することによって $\sigma_{\mathrm{Fe}} \mathrm{d}$ の值の妥当性について 検討する。

$\sigma^{\mathrm{d}}$ q, $\alpha, \mathrm{I} \varepsilon$ 関係について, 次の式がLondon ${ }^{17) に よ ~}$ って与えられている。

$$
\sigma^{\mathrm{d}}=(\pi / 8)\left(\mathrm{q}^{2} \alpha^{2} \mathrm{I} / \mathrm{d}^{2}\right)
$$

(2) 式は，(9)式を(8)式に代入して得られたものであ る。

他方，（4)，（5)式より(10)式が得られる。

$$
\sigma_{\mathrm{Fe}}{ }^{\mathrm{d}}=(3 / 2) \pi \mathrm{d}_{\mathrm{Al}_{2} \mathrm{O}_{3}}{ }^{2}\left(\mathrm{~W}_{\mathrm{ad}}\right)^{2} / \mathrm{A}_{\mathrm{Al}_{2} \mathrm{O}_{3}}
$$

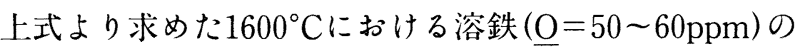
$\sigma_{\mathrm{Fe}}{ }^{\mathrm{d}}$ が, $0.83 \mathrm{~N} / \mathrm{m}$ なる。また, この条件での $\sigma_{\mathrm{Fe}}$ は, 森 ら ${ }^{13)}$ の測定によると，1.72N/mであり，そこで，このとき の $\sigma_{\mathrm{Fe}}^{\mathrm{d}} / \sigma_{\mathrm{Fe}}$ の值は 0.48 とる。

また，溶鉄の場合と同様の方法で，元素周期表でFeの位 置と近い同じ溶融金属である $\mathrm{Cu}, \mathrm{Ni}, \mathrm{Cr} の \sigma^{\mathrm{d}} / \sigma$ 值を計算 してみる。

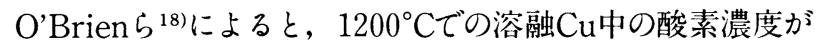
$1 \mathrm{ppm}$ 程度であれば, $\mathrm{Cu} と \mathrm{Al}_{2} \mathrm{O}_{3}$ の界面において解離反応あ るいは複合酸化物の生成反応が起こらず,この際の付着仕

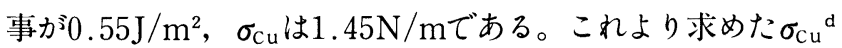
は $0.70 \mathrm{~N} / \mathrm{m}, \sigma_{\mathrm{Cu}}{ }^{\mathrm{d}} / \sigma_{\mathrm{Cu}}$ は 0.48 となる。

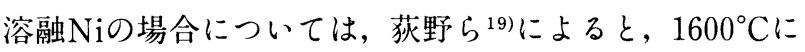
おいて, $\mathrm{Ni}$ 中の酸素濃度が30〜 50ppmのとき, $\mathrm{Ni}$ と $\mathrm{Al}_{2} \mathrm{O}_{3}$ の界面で反応が起こらず，この際の付着仕事が $0.61 \mathrm{~J} / \mathrm{m}^{2}$, $\sigma_{\mathrm{Ni}}{ }^{\mathrm{d} カ 3} 1.65 \mathrm{~N} / \mathrm{m} て ゙ あ る 。 こ れ よ り ， \sigma_{\mathrm{N} 1}{ }^{\mathrm{d}}$ は $0.86 \mathrm{~N} / \mathrm{m}, \sigma_{\mathrm{N} 1}{ }^{\mathrm{d}} /$ $\sigma_{\mathrm{Ni}}$ は 0.52 と求められる。

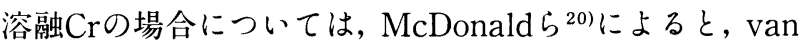


der Waals力に基づく $\mathrm{Cr}$ と $\mathrm{Al}_{2} \mathrm{O}_{3}$ の付着仕事は $0.59 \mathrm{~J} / \mathrm{m}^{2}$ であ

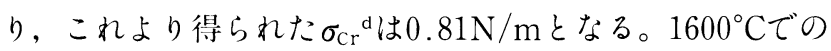
$\sigma_{\mathrm{cr}}$ を $\left.1.78 \mathrm{~N} / \mathrm{m}^{6}\right)$ とすれば, $\sigma_{\mathrm{Cr}}{ }^{\mathrm{d}} / \sigma_{\mathrm{Cr}}$ が $^{\mathrm{r}} 0.45$ となる。

以上求めた $\sigma^{\mathrm{d}} / \sigma$ Fig. 2 に図示寸る。Fig. 2 から,これら の溶融金属の $\sigma^{\mathrm{d}} / \sigma$ の值がおおよそ一致しており，大体 0.40 0.50程度であることがわかる。これによって, 本研 究で得られた $\sigma_{\mathrm{Fe}} \mathrm{d} の$ 值は, 近似的には妥当であると推定され る。

一方, 本研究で得られた $\mathrm{A}_{\mathrm{Fe}}, \mathrm{A}_{\mathrm{AFA}}, \mathrm{A}_{\mathrm{AFB}}$ の値を固体鉄

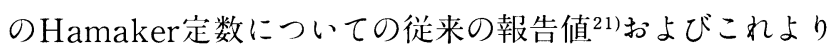
推定した $\mathrm{A}_{\mathrm{AFA}}, \mathrm{A}_{\mathrm{AFB}}$ の値)とともにTable 2 にまとめる。

Table 2 から, 本研究で得られた $1600^{\circ} \mathrm{C} て ゙ の$ 溶鉄 $(\underline{O}=$ $50 \sim 60 \mathrm{ppm})$ の Hamaker定数は，固体鉄の報告值 $(2.12 \times$ $\left.10^{-19} \mathrm{~J}\right)$ に較べて約 5 倍大きいことがわかる。しかし，これ は, 鉄の融解に伴って鉄のHamaker定数が大きく変わるこ とを意味しているかぞうかは，現段階では不明である。

固体鉄のHamaker定数の報告值は, Visser ${ }^{21}$ 力 $^{\mathrm{F}} \mathrm{Fowkes}^{22)}$ の報告した固体鉄の $\sigma^{\mathrm{d}}(0.098 \mathrm{~N} / \mathrm{m})$ から求めたものであるが, その $\sigma^{\mathrm{d} の}$ 測定方法および測定に用いた鉄の組成についての 詳細が不明である。したがって，その報告值の妥当性およ び本研究結果との差異の原因について論ずることはできな い。

また，Hamaker定数は，（８)式によって定義されている が, 鉄の融解に伴ってqの变化が密度の変化から推定できる ものの, $\alpha, I の$ 変化蝴らかではないので, 推定すること が困難である。

一方, Table 2 より, 本研究で求めた溶鉄のHamaker定 数が固体鉄のそれより約 5 倍大きいのに対して，それぞれ

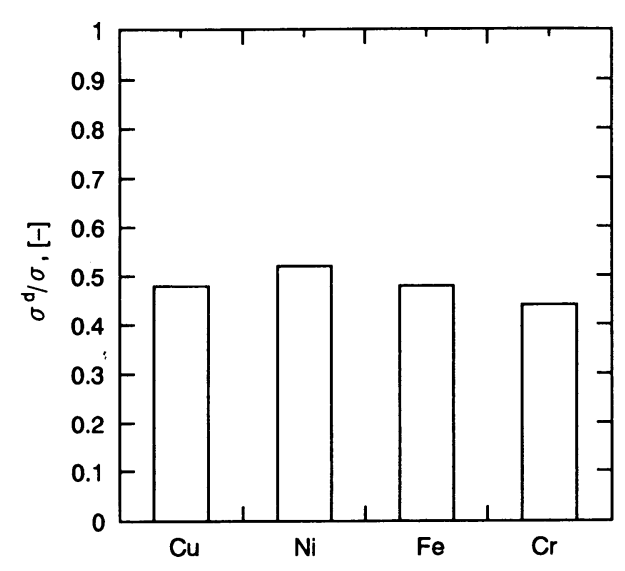

Fig. 2. Comparision of $\sigma^{\mathrm{d}} / \sigma$ of molten $\mathrm{Cu}, \mathrm{Ni}, \mathrm{Fe}$, $\mathrm{Cr}$.

Table 2. Comparision of results obtained with two methods.

\begin{tabular}{|c|c|c|c|}
\hline$A_{F e} / 10^{-19} \mathrm{~J}$ & $A_{A F A} / 10^{-19} \mathrm{~J}$ & $A_{A F B} / 10^{-19} \mathrm{~J}$ & Methods \\
\hline 10.5 & 3.98 & 6.47 & Eq.(5),(6), (7) \\
2.12 (Solid iron) & 0.045 & 0.0307 & Ref.5 \\
\hline
\end{tabular}

から求めた溶鉄中の $\mathrm{Al}_{2} \mathrm{O}_{3} / \mathrm{Al}_{2} \mathrm{O}_{3}$ および $\mathrm{Al}_{2} \mathrm{O}_{3} /$ 気泡の Hamaker定数にはいずれも約 2 桁もの差が出ていることが わかる。これは, Fig. 3 に示しているように, $\mathrm{A}_{\mathrm{AFA}}$ や $\mathrm{A}_{\mathrm{AFB}}$ は $\mathrm{A}_{\mathrm{Fe}}$ の見積りの精度によって大きく变化するためと考えら れる。

\section{$4 \cdot 2 \mathrm{Al}$ キルド溶鋼中のHamaker定数の推算}

$\mathrm{A} 1$ キルド鋼は最も大量に製造されている鋼種の 1 つで, その代表的な化学組成をTable 3 に示寸。この鋼種の介在物 は, 脱酸生成物の $\mathrm{Al}_{2} \mathrm{O}_{3}$ が主体である。

S以外の元素は濃度が低く, Hamaker定数に対する影響

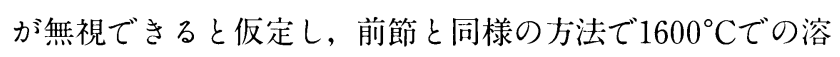
鋼および溶鋼中 $\mathrm{Al}_{2} \mathrm{O}_{3} / \mathrm{Al}_{2} \mathrm{O}_{3}, \mathrm{Al}_{2} \mathrm{O}_{3} /$ 気泡のHamaker定数 $\left(\mathrm{A}_{\mathrm{Stee} 1}, \mathrm{~A}_{\mathrm{ASA}}, \mathrm{A}_{\mathrm{ASB}}\right)$ を求め, その結果をFig. 4 に示寸。異

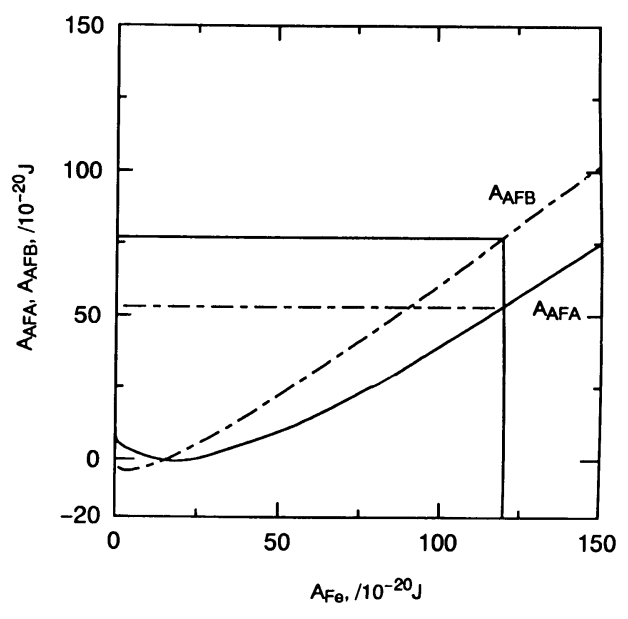

Fig. 3. Relationship between Hamaker constant of molten iron and that of $\mathrm{Al}_{2} \mathrm{O}_{3} / \mathrm{Al}_{2} \mathrm{O}_{3}, \mathrm{Al}_{2} \mathrm{O}_{3} /$ bubble in molten iron at $1600^{\circ} \mathrm{C}$.

Table 3. Typical composition of Al killed steel.

\begin{tabular}{|c|c|c|c|c|c|c|c|}
\hline $\mathrm{C}$ & $\mathrm{Si}$ & $\mathrm{Mn}$ & $\mathrm{P}$ & $\mathrm{S}$ & $\mathrm{N}$ & sol.Al & sol.0 \\
\hline $0.003-0.2$ & 0.02 & $0.1-0.3$ & 0.02 & $0.005-0.03$ & 0.003 & 0.05 & $5-10 \mathrm{ppm}$ \\
\hline
\end{tabular}

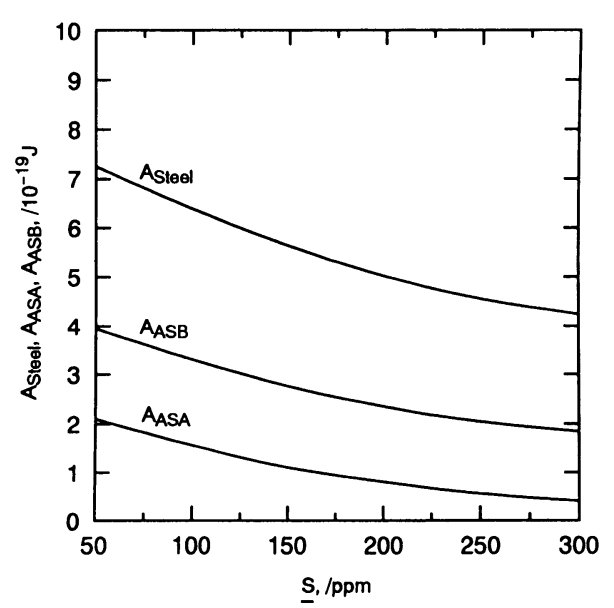

Fig. 4. Relationship between sulfur concentration and $\mathrm{A}_{\text {Steel }}, \mathrm{A}_{\mathrm{ASA}}, \mathrm{A}_{\mathrm{ASB}}$ in molten steel at $1600^{\circ} \mathrm{C}$. 
なるS濃度での溶鉄と $\mathrm{Al}_{2} \mathrm{O}_{3}$ の付着仕事として，荻野ら ${ }^{23)} の$ 測定值を用いた。

Fig. 4 より，S濃度が50ppmから300ppmまで高くなると，

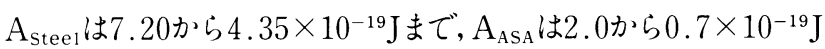
まで， $\mathrm{A}_{\mathrm{ASB}}$ は3.86から $1.75 \times 10^{-19} \mathrm{~J}$ まで小さくなることがわ かる。S濃度が通常の $100 \mathrm{ppm}$ 程度である場合， $\mathrm{A}_{\text {steel }}$ は $6.53 \times 10^{-19} \mathrm{~J}, \mathrm{~A}_{\mathrm{ASA}}$ は $1.70 \times 10^{-19} \mathrm{~J}, \mathrm{~A}_{\mathrm{ASB}}$ は3 $3.35 \times 10^{-19} \mathrm{~J}$ なる。

\section{$4 \cdot 3$ 溶鋼乱流場での $\mathrm{Al}_{2} \mathrm{O}_{3}$ 介在物の凝集係数}

流体中の粒子間力として，van der Waals力のみが作用 寸る場合の凝集係数 $\alpha_{\mathrm{T}}$ と 1 つの無次元因子である $\mathrm{N}_{\mathrm{T}}[=(6$ $\left.\left.\pi \mu \mathrm{a}_{\mathrm{ij}}{ }^{3} / \mathrm{A}\right)(4 \varepsilon / 15 \pi \nu)^{1 / 2}\right]$ との関係は, Higashitani ${ }^{2) に よ ~}$ つて定量的に求めれている。ここで， $\mu$ は流体の粘度， $\nu$ は 動粘度, $\varepsilon$ は消散エネルギー, $\mathrm{a}_{\mathrm{ij}}=\left(\mathrm{a}_{\mathrm{i}}+\mathrm{a}_{\mathrm{j}}\right) / 2, \mathrm{a}_{\mathrm{i}}, \mathrm{a}_{\mathrm{j}}$ は粒 子の半径, Aは流体中の粒子間のHamaker定数である(本研 究の $\mathrm{A}_{\mathrm{AFA}}$ または $\mathrm{A}_{\mathrm{ASA}}$ に相当する)。

溶鋼中の介在物間力としてvan der Waals力のみを考え， また溶鋼の $\mu$ が $6 \times 10^{-3} \mathrm{~N} \cdot \mathrm{s} / \mathrm{m}^{2}, \nu$ が $8 \times 10^{-7} \mathrm{~m}^{2} / \mathrm{s}^{24)}$ なの で, Higashitaniらの結果より求めた 集係数と溶鋼中介在物のHamaker定数との関係をFig. 5 に 示す。Fig. 5 より, 介在物間のHamaker定数が大きいほど, 凝集係数も大きくなることがわかる。

S濃度が100ppmのAlキルド鋼では， $\mathrm{A}_{\mathrm{ASA}}$ を $1.70 \times 10^{-19} \mathrm{~J}$ として，Fig. 5 から，このとき半径が $2 \mu \mathrm{m} の \mathrm{Al}_{2} \mathrm{O}_{3}$ 介在物 の凝集係数は約 0.4 となることがわかる。

一方, Nakanishi $5^{25)}$ は, 各種の攪拌条件 $(\varepsilon=0.008$ $0.012 \mathrm{~J} / \mathrm{kgs}$ ) での溶鋼中の $\mathrm{Al}_{2} \mathrm{O}_{3}$ の除去速度を実験的に調 心，凝集係数を求めた。脱酸速度の実験值から求めた消散 エネルギーと流体力学の式から求めたそれとの比の $1 / 2$ 乗と 定義して, 求めた凝集係数は，0.3〜0.6となっている。ま た鋼中介在物の平均半径が $1 \sim 3 \mu \mathrm{m}$ 程度であることを示し た。

本研究によるHamaker定数を用いてHigashitaniらの求め

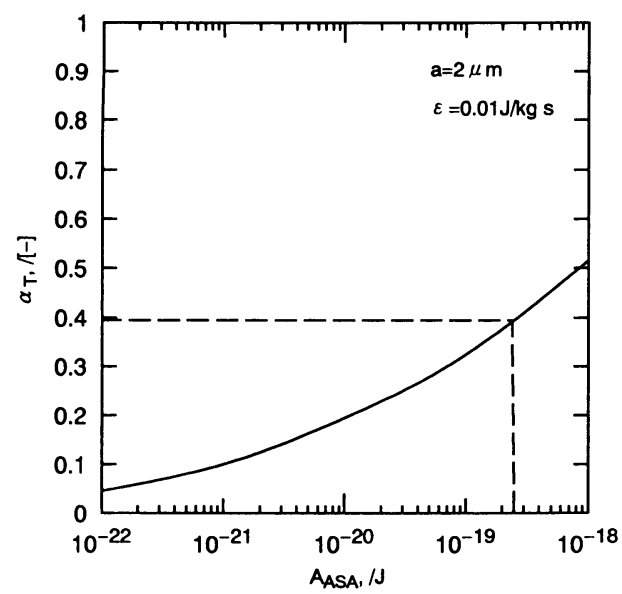

Fig. 5. Relationship between coagulation coefficient and Hamaker constants of inclusion in molten steel at $1600^{\circ} \mathrm{C}$.
た関係から算出した凝集係数は，Nakanishiらと比較すると 大略一致しているが，詳細は今後検討することが必要であ る。

\section{$4 \cdot 4$ 介在物の除去に有利な気泡の大きさの見積り}

溶鋼中 $\mathrm{Al}_{2} \mathrm{O}_{3}$ と気泡間のHamaker定数 $\mathrm{A}_{\mathrm{ASB}}$ の值が正の值 であるので，その間のvan der Waals力は引力として働き， 寸なわち，気泡の捕捉による介在物除去の可能性があると 考えられる。

ガスを取鍋の底から吹込み，生成した気泡が浮上中に介 在物と衝突付着が生じて，介在物が除去されるモデルを考 える。浮遊選鉱理論によれば，溶鋼中介在物個数濃度Nの 変化率は次の式で表せる ${ }^{26)}$ 。

$$
\mathrm{dN} / \mathrm{dt}=-(3 / 2)\left(\mathrm{V}_{\mathrm{g}} / \mathrm{d}_{\mathrm{b}}\right) \mathrm{P}_{\mathrm{c}} \mathrm{P}_{\mathrm{a}} \mathrm{N}
$$

tは時間, $\mathrm{d}_{\mathrm{b}}$ は気泡の直径, $\mathrm{V}_{\mathrm{g}}=\mathrm{QH} / \mathrm{V}_{1}, \mathrm{~V}_{1}$ は溶鋼の体積, $\mathrm{H}$ は溶鋼の高さ，Qはガス流量, $\mathrm{P}_{\mathrm{c}}, \mathrm{P}_{\mathrm{a}}$ はそれぞれ介在物と 気泡の衝突確率と付着確率である。

Sutherland ${ }^{27)}$ の解析によると，介在物の洎径を $\mathrm{d}_{\mathrm{p}}$ をすれ ば, $\mathrm{P}_{\mathrm{c}}=3\left(\mathrm{~d}_{\mathrm{p}} / \mathrm{d}_{\mathrm{b}}\right)$ となる。

$\mathrm{P}_{\mathrm{a}}$ については, Yoonら ${ }^{28)}$ は， $\mathrm{P}_{\mathrm{a}}$ と気泡に接近した粒子(介 在物)の気泡に付着する誘導時間 (Inductin time) $t_{i}$ との関係 式を導いた。 $t_{i}$ は付着の駆動力となるvan der Waals力の増 加につれて減少し, 水溶液の場合は $\mathrm{t}_{\mathrm{j}}$ は通常 $0.1 \sim 10 \mathrm{~ms}$ の範 囲にある。水溶液中の粒子と気泡のHamaker定数は大体 $10^{-20} \sim 10^{-21} \mathrm{~J}$ 程度で, 本研究で求めた $\mathrm{A}_{\mathrm{ASB}}$ の值はそれらよ

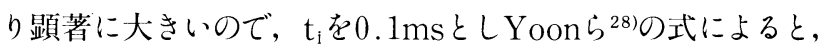
$10 \mu \mathrm{m}$ 以下の介在物に対して, 気泡の直径が $10 \mathrm{~mm}$ 以下なら ば, $\mathrm{P}_{\mathrm{a}}$ は0.1〜 1 の間にあると推定される。

取鍋直径を $3 \mathrm{~m}$, ガスの全流量を $10^{-2} \mathrm{~m}^{3} / \mathrm{s}$ とすると, $\mathrm{V}_{\mathrm{g}}=$ $10^{-3} \mathrm{~m} / \mathrm{s}$ (現場のガスバブリング条件に近い)となる。15分間 の処理前後における直径 $10 \mu \mathrm{m}$ の介在物の变化率と気泡直径 との関係を(11) 式から求め, Fig. 6 に示す。Fig. 6 から, 15 分間以内で $10 \mu \mathrm{m}$ の介在物を $80 \%$ 以上除去寸るためには，気

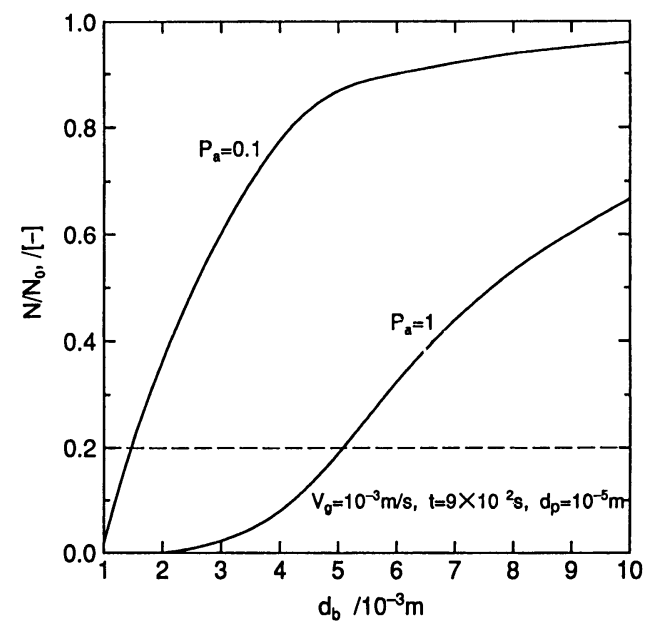

Fig. 6. Relationship between change rate of inclusion number and diameter of bubbles. 
泡の直径を $5 \mathrm{~mm}$ 以下に制御することが必要であり，最も有 利な気泡の直径は $1.5 \mathrm{~mm}$ 以下であると推定される。

\section{5. 結言}

1 ) Fowkesの方法を用いて，常温での $\mathrm{Al}_{2} \mathrm{O}_{3}$ の Hamaker 定数, 溶鉄 $(\underline{\mathrm{O}}=50 \sim 60 \mathrm{ppm}) \prec \mathrm{Al}_{2} \mathrm{O}_{3}$ の付着仕事より $1600^{\circ} \mathrm{C}$ での溶鉄のHamaker定数 $\mathrm{A}_{\mathrm{Fe}}$, 溶鉄中の $\mathrm{Al}_{2} \mathrm{O}_{3} / \mathrm{Al}_{2} \mathrm{O}_{3}$ お び $\mathrm{Al}_{2} \mathrm{O}_{3}$ /気泡のHamaker定数 $\mathrm{A}_{\mathrm{AFA}}, \mathrm{A}_{\mathrm{AFB}}$ 畨推算した結果, 以下の值が得られた。

$$
\begin{aligned}
& \mathrm{A}_{\mathrm{Fe}}=10.5 \times 10^{-19} \mathrm{~J} \\
& \mathrm{~A}_{\mathrm{AFA}}=3.98 \times 10^{-19} \mathrm{~J} \\
& \mathrm{~A}_{\mathrm{AFB}}=6.47 \times 10^{-19} \mathrm{~J}
\end{aligned}
$$

2 ) 同様な方法で推定したS濃度が100ppmでのAlキルド 溶鋼場合の值は次のようになった。

$$
\begin{aligned}
& \mathrm{A}_{\text {steel }}=6.53 \times 10^{-19} \mathrm{~J} \\
& \mathrm{~A}_{\mathrm{ASA}}=1.70 \times 10^{-19} \mathrm{~J} \\
& \mathrm{~A}_{\mathrm{ASB}}=3.35 \times 10^{-19} \mathrm{~J}
\end{aligned}
$$

3 ) 本研究で求めたHamaker定数より $\mathrm{Al}$ キルド溶鋼中 $\mathrm{Al}_{2} \mathrm{O}_{3}$ 介在物の凝集係数を求めた結果, $\varepsilon$ が $0.01 \mathrm{~J} / \mathrm{kgs} て ゙$,

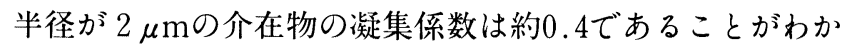
った。

4 )気泡の捕捉による介在物の除去速度について検討した

\begin{tabular}{|c|c|}
\hline A & : Hamaker定数 $(\mathrm{J})$ \\
\hline $\mathrm{A}_{\mathrm{re}}$ & : 溶鉄のHamaker定数 $(\mathrm{J})$ \\
\hline$A_{\text {stee } 1}$ & ：溶鋼のHamaker定数 (J) \\
\hline $\mathrm{A}_{\mathrm{Al}_{2} \mathrm{O}_{3}}$ & : $\mathrm{Al}_{2} \mathrm{O}_{3}$ のHamaker定数 $(\mathrm{J})$ \\
\hline $\mathrm{A}_{\mathrm{AFA}}$ & : 溶鉄中 $\mathrm{Al}_{2} \mathrm{O}_{3}$ 同士間のHamaker定数 $(\mathrm{J})$ \\
\hline $\mathrm{A}_{\mathrm{ASA}}$ & : 溶鋼中 $\mathrm{Al}_{2} \mathrm{O}_{3}$ 同士間のHamaker定数 (J) \\
\hline$A_{A F B}$ & : 溶鉄中 $\mathrm{Al}_{2} \mathrm{O}_{3}$ と気泡間のHamaker定数 $(\mathrm{J})$ \\
\hline $\mathrm{A}_{\mathrm{ASB}}$ & : 溶鋼中 $\mathrm{Al}_{2} \mathrm{O}_{3}$ と気泡間のHamaker定数 (J) \\
\hline$a_{i}, a_{j}$ & ：介在物の半径 (m) \\
\hline$a_{i j}$ & $:\left(a_{i}+a_{j}\right) / 2(m)$ \\
\hline $\mathrm{d}$ & ：分子間距離(m) \\
\hline$d_{b}$ & : 気泡の直径 (m) \\
\hline$d_{p}$ & ：介在物の直径 $(\mathrm{m})$ \\
\hline I & : 原子のイオン化ポテンシャル $(\mathrm{J})$ \\
\hline
\end{tabular}
.結果, 現場と近い条件では, 直径 $10 \mu \mathrm{m}$ の $\mathrm{Al}_{2} \mathrm{O}_{3}$ 介在物を効 率的に除去するためには, 気泡の直径を $5 \mathrm{~mm}$ 以下に制御す ることが必要であり, 最も有利な気泡の直径は $1.5 \mathrm{~mm}$ 以下 であると推定された。

\section{記 号}

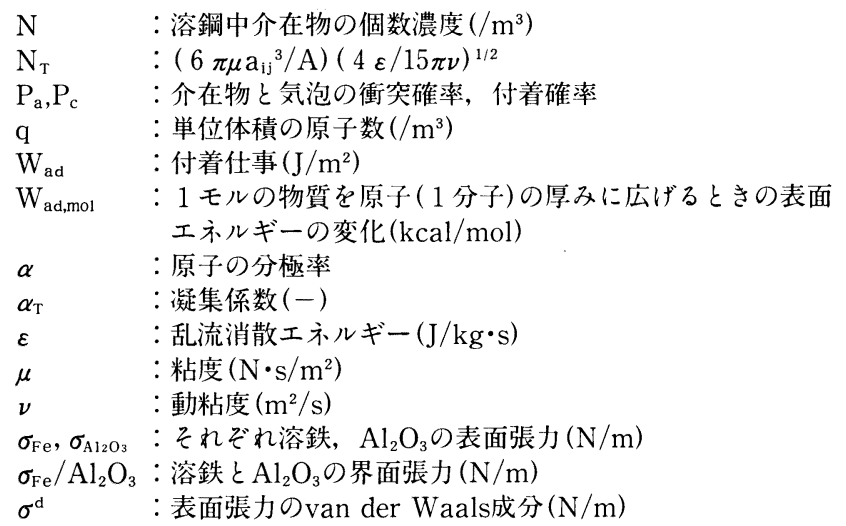

\section{文献}

1) 例えば，山田 亘，沢田郁夫，田中宏幸：材料とプロセス，9 (1996), 767.

2) K.Higashitani, K.Yamauchi, Y.Matsuno, and G.Hosokawa: J.Chem. Eng. Japan, 16 (1983), 299.

3 ) C.E.Sims: Trans. Metall. Soc. AIME, 215 (1959), 367.

4 ) 佐々木弘：ガス・気泡小委員会資料 (7-5), 日本学術振興会製鋼 19 委員会, (1993)

5 ) 谷口尚司, 菊池 淳：鉄 鋼, 78 (1992), 527.

6 ）第4版 化学便覧·基礎II, 日本化学会編, 丸善, 東京, (1993), 100.

7 ) F.M.Fowkes : Ind. Eng. Chem., 56 (1964), 40.

8 ) G.Bohme, H.Krupp, and W.Schnabel : Molecular Processes at Solid Surfaces, McGraw-Hill Book Co., New York, (1969), 611.

9 ) H.Buttner, E.Gerlach: Chem. Phys. Lett., 5 (1970), 91.

10) D.B.Houng and L.R.White: Adv. Colloid Interface Sci., 14 (1980), 3.

11) L.Bergstrom, A.Meurk, H.Arwin, and D.J.Rowcliffe: J.Am. Ceram. Soc., 79 (1996), 339.

12）荻野和已，足立 彰，野城 清：鉄 $\xi$ 鋼，59（1973）, 1237

13）森 克也, 中島邦人, 滝平憲治：介在物小委員会資料, 日本学術 振興会製鋼19委員会, (1991)，11；20.

14）早稲田嘉夫, 徳田昌則, 大谷正康：鉄 鋼, 61 (1975), 54 .

15）分散・凝集の解明と応用技術，北原文雄監修，テクノシステム, 東 京, (1992).

16) H.C.Hamaker: Physica, 4 (1937), 1058

17) F.London: Trans.Faraday Soc., 33 (1937), 8

18) T.E.O'brien and A.C.D. Chaklader: J.Am. Ceram. Soc., 57 (1974), 329

19）荻野和巳，泰松 斉：日本金属会誌，43（1979），871

20) J.E.McDonald and J.G.Eberhart: Trans. Metall. Soc. AIME, 233 (1965), 512.

21) J.Visser: Adv. Colloid Interface Sci., 3 (1972), 73.

22) F.M.Fowkes: Surfaces and Interfaces, 1 (1967), 199

23）荻野和已，野城 清，山瀬 治：鉄 $飞$ 鋼, 59 (1980), 179.

24）溶鉄・溶涬の物性值便覧，日本鉄鋼協会鉄鋼基礎共同研究会編 東京, (1972)，32.

25) K.Nakanishi and J.Szekely: Trans. Iron Steel Inst. Jpn., 15 (1975), 522.

26) G.J.Jameson, S.Nam and M.Young: Miner. Sci. Eng., 9 (1977), 103.

27) K.L.Sutherland: J.Phys. Chem., 52 (1984), 394.

28) R.H.Yoon: Miner. Process. Extr. Metall. Rev., 5( 1989), 101. 